\title{
大気圧プラズマを用いた円筒型高分子材料の表面改質
} 小田川 健二*1. 貞本 満*1. 小野 茂*2

\section{Surface Treatment of Cylinder-shaped Polymer Materials Using Atmospheric-pressure Plasma}

\section{Kenji ODAGAWA*1, Mitsuru SADAMOTO*1 and Shigeru ONO*2}

\author{
${ }^{* 1}$ Mitsui Chemicals, Inc., 580-32 nagaura, sodegaura-city, chiba 299-0265 \\ *2Musashi Institute of Technology, 1-28-1 tamadutsumi, setagaya-ku, tokyo 158-8557
}

(Received September 6, 2005, Accepted August 5, 2006)

\begin{abstract}
A treatment apparatus using atmospheric-pressure plasma was newly developed to treat the inner-surface of tube connectors for medical use. Improving the structure of opposed coaxial electrodes and applying time-modulated RF power between the electrodes enabled uniform inner-surface treatments that did not necessarily need rare gas. In the treatments using nitrogen or helium, the contact angle of water droplets lower than $20 \mathrm{deg}$ was obtained. The mechanism of the good hydrophilic property was discussed using the results of optical emission spectroscopy of plasma, x-ray photoelectron spectroscopy and contact angle of water droplets on a treated surface.
\end{abstract}

\section{1. はじめに}

大気圧下の放電プラズマ処理は，(1)真空装置が不要であ り，インラインの連続処理が容易になる，(2)真空方式に比べ 設備費が安価である, (3)処理したい部分にだけにプラズマを つくり照射する事ができる等の特徵を有しており, 注目を集 めている表面処理法である1,2).

大気圧下の放電プラズマを用いた円筒型高分子材料の表面 処理の応用に関しては, ポリマーチューブ内面のプラズマ処 理が良く知られている. ポリ塩化ビニル (PVC) チューブ は, 環境ホルモンとして問題視されている可塑剤を多く含ん でいる事から, 可塑剤の溶出防止のために, 大気圧グロー放 電によるチューブ内面へのプラズマ重合処理が試みられた ${ }^{2)}$.

一方，チューブ以外の円筒型高分子材料の 1 つに，医療 用に使われるチューブコネクタがある。これは, 長さが 20 $\mathrm{mm}$ 程度の筒状の部材であり, 医療用チューブ同士を接続す るために使われる.チューブとコネクタの固定には, 接着剤 を用い, コネクタの両サイドからチューブを挿入して使用す る.このコネクタには, 材質によってチューブとの接着性が 悪いという問題があった.

そこで, 接着性を改善するために, 大気圧下での放電プラ ズマ処理によるコネクタの内面の親水化を検討した. コネク タの長さが短いため, 放電プラズマ処理に用いる電極は, チ ューブの内面処理に用いられた 2 重螺旋型ではなく, 従来 から種々の放電装置 ${ }^{3}$ に使われている同軸対向型を採用し た。しかしながら，一般的に使われている13.56 MHz の高 周波 $(\mathrm{RF})$ をこの方式に利用しようとすると, 安定な放電 プラズマを形成するために, $\mathrm{He}$ や $\mathrm{Ar}$ 等の高価な希ガスが 必要とし, 窒素ガスを用いた放電プラズマの形成が難しい.

筆者らは, 既報4)のコロナトーチの改良に関する知見を応

*1 三井化学侏マテリアルサイエンス研究所（テ299-0265 千葉県 袖ヶ浦市長浦580-32)

*2 武蔵工業大学 工学部電気電子工学科（一158-8557 東京都世 田谷区玉堤 1-28-1)
用する事を試みた. その結果, 電極構造と RF 電力の印加方 法を工夫することで, 希ガスを必ずしも必要としない均質な 内面処理が可能である事を見出した. 本報告では, 種々のガ スを用いた場合におけるコネクタ用の内面大気圧プラズマ処 理装置の放電特性, 及びコネクタ内面の放電プラズマ処理特 性を系統的に調べた結果について述べる.

\section{2. 実験方法}

\section{1 コネクタ内面の放電プラズマ処理}

コネクタ内面用大気圧プラズマ処理装置の概略図を Fig. 1 に示す. 本装置では, コネクタの内側と外側に電極を配置 した同軸対向型の電極構造を採った. 内側を接地電極, 外側 $\mathrm{RF}$ 電極とし, 接地電極には, 表面に微小な螺旋溝を形成し たものを使用した。これには，次の効果を期待した。

(a) 螺旋溝の凹凸で電界を局所的に集中させる事ができ, $\mathrm{N}_{2}$ や空気のような He に比べ放電しにくいガス種でも低パ ワーでの放電形成を容易する4).

(b) 螺旋溝により, プラズマを形成する微小空間を確保で

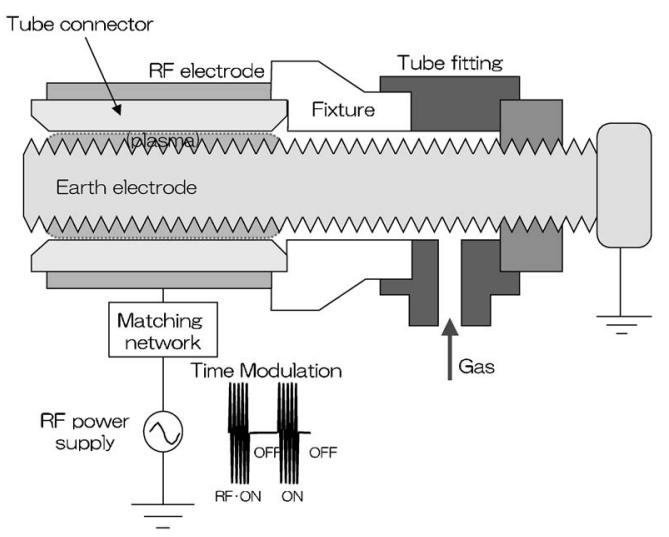

Fig. 1 Experimental apparatus for inner-surface treatment of cylindrical polymer materials using atmospheric-pressure plasma generated by opposed coaxial electrodes. 
きると同時に，安定したガスフローを保証することができ， 均質な内面処理ができる.

さらに，時間変調した $13.56 \mathrm{MHz}$ の $\mathrm{RF}$ 電力を，整合回 路を介して RF 電極と接地電極との間に印加した。これに は, 次の効果を期待した.

(c) 電力印加の断続が活性種の生成過程に大きく影響し, $\mathrm{N}_{2}$ のような $\mathrm{He}$ に比べ放電しにくいガス種でも低パワーで の放電形成が容易になる4 ${ }^{4}$.

コネクタ内面のプラズマ処理は，電極間に試料を設置し， 接地電極と試料の間にガスを導入した後, $\mathrm{RF}$ 電力を印加し て，放電プラズマを形成することで行った．時間変調の条件 は，コネクタが熱的なダメージを受けないように，変調周波 数を $600 \mathrm{~Hz}$ ，デューティ・サイクルを 0.01 とした.ここ で, デューティ・サイクルとは, 変調周期中に $\mathrm{RF}$ 電力を印 加している期間の比率である. 投入電力は, $\mathrm{RF}$ 電力を印加 している期間の投入電力で表した. 時間平均の投入電力は, デューティ・サイクルを乗じた值となる．また，ガスは， $\mathrm{He}, \mathrm{He}+1 \% \mathrm{O}_{2}, \mathrm{Ar}, \mathrm{N}_{2}$ 及び空気 (AIR) の 5 種を使用し， 処理特性の違いを系統的に調べた。ガスの総流量は $0.5 \mathrm{l} /$ min.とした.

試料は, 外径 $4.4 \mathrm{~mm}$, 内径 $3.2 \mathrm{~mm}$, 長さ $20 \mathrm{~mm}$ のポリプ ロピレン (PP) ベースの材料と, 参考のため外径 $6.0 \mathrm{~mm}$, 内径 $4.0 \mathrm{~mm}$, 長さ $20 \mathrm{~mm}$ の組成が単純な高密度ポリエチレ ン（HDPE）の 2 種を用いた。 それに伴い，接地電極は，そ れぞれステンレス製の M3 ネジ，M4 ネジを用いた． RF 電 極は，それぞれのコネクタの外径に合わせて用意した。

また，汎用の処理装置として，一般的な平行平板型の低圧 プラズマ処理装置を選び，コネクタ内面の処理特性を比較し た. 低圧プラズマ処理では，コネクタはアノード電極に垂直 に設置して処理した.さらに，コネクタの上下を反転させ， 再度処理した。低圧プラズマの条件は，圧力を $20 \mathrm{~Pa}$, 電極 間隔を $70 \mathrm{~mm}$ ，投入電力を $100 \mathrm{~W}\left(1.3 \mathrm{~W} / \mathrm{cm}^{2}\right)$ とした.

\section{2 放電プラズマ処理したコネクタ内面の評価方法}

放電プラズマ処理によるコネクタの内面の状態変化は, 処 理面の表面エネルギーに関係する水滴接触角と, 表面の化学 結合状態の情報が得られる X 線光電子分光法 (XPS) よる 分析から評価した。

コネクタ内面の水滴接触角の測定方法を Fig. 2 に示す. 測定試料は，コネクタを $4 \mathrm{~mm}$ 程度の長さに切り出し，それ を半割したものを用いた。協和表面科学侏製の接触角計 (CA-X 型) により，測定試料に $1 \sim 2 \mu l$ の水滴を基材に滴 下した後, 10 秒間待って, 水滴接触角を測定した.この場 合, 液滴の観察画像から, 画像解析により接触角を求める. 具体的には, 液滴と基材の形状は, 円の一部として近似でき るものとし, 液滴の底面の両端と上端の 3 点を指定して接 触角を算出した．この方法により，Fig. 2 に示す $\Theta_{1}, \Theta_{2}$ を 求める事ができ, 同一の観察画像に対する $\Theta_{1}, \Theta_{2}$ の測定結 果から, コネクタ内面の水滴接触角 $(\Theta)$ を算出した。この 方法により測定した未処理時のコネクタ内面の水滴接触角 は, PP 製の場合 $110 \mathrm{deg}, \mathrm{HDPE}$ 製の場合108 deg だった。

XPS 分析には, VG Scientific 社製 ESCALAB220 IXL （X 線源は $\mathrm{Mg}-\mathrm{K} \alpha$ ）を用いた．Ｃ 1s，O 1s 及び N 1s スペク

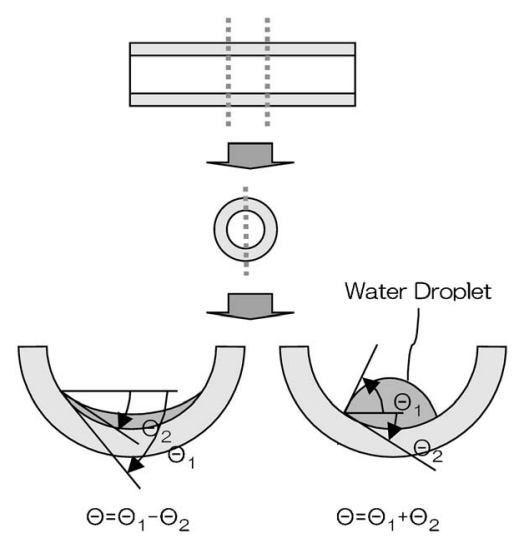

Fig. 2 Measuring method of contact angle $(\theta)$ of water droplets on inner-surface of rigid cylindrical polymer materials.

トルは, エネルギー間隔 $0.1 \mathrm{eV}$ で測定し, 各ピーク面積か ら処理表面の組成比を求めた．C 1s スペクトルは, 文献5,6) を参考にして 4 つのピークに分離し, 処理表面での炭素の 化学結合状態を評価した.

\section{3 放電プラズマの発光分光分析}

放電プラズマのガス種による違いを定性的に調べるため に, ガスの下流側から発光分光 (OES) 測定を行った。測 定には，浜松ホトニクス製プラズマプロセスモニタ C7460 を用いた．測定した発光ピークの帰属は, 文献 7),8）を参考 に決定した。

\section{3. 実 験 結 果}

\section{1 コネクタ内面処理装置の放電特性}

試作した装置の放電特性における接地電極に形成した螺旋 溝と $\mathrm{RF}$ 電力の時間変調の効果を調べた. 接地電極に溝の無 い電極構成を Type A, 接地電極に螺旋溝を形成した電極構 成を Type B とする. HDPEコネクタを電極間に設置し て, 種々のガスを用いた場合の放電開始電力を調べた結果を Fig. 3 に示す. ある一定の電力を処理装置に印加して放電 が開始されるかどうかを観察する試験を繰り返し，放電が開 始される最低電力を放電開始電力とした. Type A の接地電 極には, Type B の接地電極に形成した溝の底部の径とほぼ 等しい $1 / 8$ インチの SUS 製ロッドを用いた.

Fig. 3 から, 接地電極に形成した螺旋溝, 及び RF 電力の 時間変調は, ともに放電開始電力の低減に効果がある事がわ かる. 両方用いた Type B (TM-On) の場合が, 最も放電 開始電力が低い. 特に, $\mathrm{N}_{2}$ と AIRの場合にその効果が顕著 である。因みに， RF 電力をコネクタの内側の電極に印加し て, 外側の電極を接地した場合でも, 同様の結果が得られた.

以上の結果から，2.1節で述べた当初期待した効果(a)及び (c)を確認することができた.

\section{2 コネクタ内面の放電プラズマ処理特性}

前節の結果を受け, 最も低い高周波電力で放電の形成が可 能な組み合わせである, 接地電極に溝を形成した電極構造 （Type B）を用い，且つ RF 電力を時間変調した場合に着目 して，放電プラズマ処理特性を調べた.

(1) ガス種の影響 

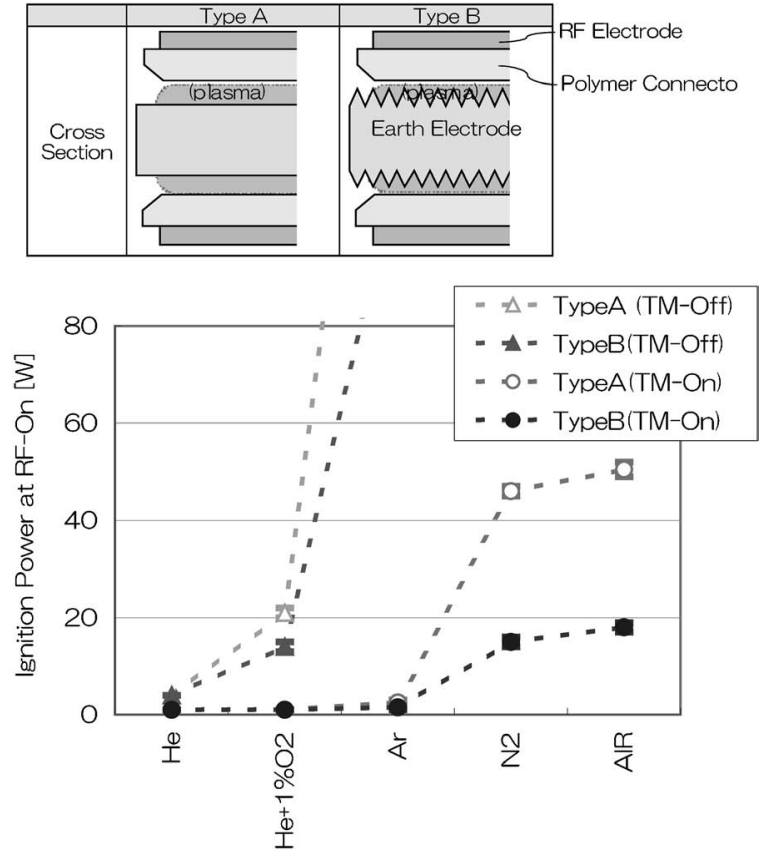

Fig. 3 Effects of electrodes and time-modulation (TM) of RF power on ignition $\mathrm{RF}$ power of atmospheric-pressure plasma generated by opposed coaxial electrodes under various gas conditions. The type electrode is defined in the upper figure. Ignition $\mathrm{RF}$ power indicates the input of power needed at RFOn to ignite the plasma. The total gas-flow rate was $0.5 \mathrm{l} /$ $\mathrm{min}$. The conditions of the time modulation were a frequency of $600 \mathrm{~Hz}$ and a duty cycle of 0.01 .

種々のガスについて, PP 及び HDPE コネクタ内面の水 滴接触角の処理時間依存性を調べた結果を Fig. 4 に示す. HDPE に比べPPの方が，短時間で処理した時の接触角が 大きく, 親水化し難い傾向を示したものの，水滴接触角の処 理時間依存性におけるガス種に対する影響は，同様な傾向を 示した. ガス種に対する水滴接触角の序列は, コネクタの材 質によらず $\mathrm{He}+1 \% \mathrm{O}_{2}>\mathrm{Ar}>\mathrm{AIR}>\mathrm{N}_{2} \sim \mathrm{He}$ である。 また， $\mathrm{N}_{2}$ と $\mathrm{He}$ では, 水滴接触角は処理時間の増加に伴い非常に 低い值を示すのに対し, $\mathrm{AIR}, \mathrm{He}+1 \% \mathrm{O}_{2}$ 及び $\mathrm{Ar}$ では, 水 滴接触角は処理時間の増加に伴い減少するものの，30～ 50 $\operatorname{deg}$ のあ一定值に落ち着く傾向を示した.

さらに，処理時間を 30 秒に固定し，HDPEコネクタ内面 の水滴接触角の投入パワ一依存性を種々のガスについて調べ た結果を Fig. 5 に示す。図中の水滴接触角が約 $108 \mathrm{deg}$ と なるプロットは，その条件の投入電力では放電プラズマを形 成できない事を示している，言い換えれば，そのプロットの 投入電力の大きさが放電のし難さを表している. ガス種に対 するその序列は， $\mathrm{He} \sim \mathrm{He}+1 \% \mathrm{O}_{2}<\mathrm{Ar}<\mathrm{N}_{2}<\mathrm{AIR}$ である. 一方, 投入電力が十分大きい $40 \mathrm{~W}$ の場合における水滴接触 角の序列は, Fig. 4 と同様に $\mathrm{He}+1 \% \mathrm{O}_{2}>\mathrm{Ar}>\mathrm{AIR}>\mathrm{N}_{2}$ 〜 $\mathrm{He}$ である. また， $\mathrm{N}_{2}$ と AIR では，水滴接触角は投入電力 の増加に伴い徐々に減少する傾向を示すのに対し, $\mathrm{He}, \mathrm{He}$ $+1 \% \mathrm{O}_{2}$ 及び $\mathrm{Ar}$ では，水滴接触角は投入電力の増加に伴い 減少するものの, 一定值に落ち着く傾向を示した.

以上から， $\mathrm{N}_{2}$ と $\mathrm{He}$ を用いて処理した場合に，コネクタ の材質によらず, $20 \mathrm{deg}$ 以下の低い水滴接触角が得られる

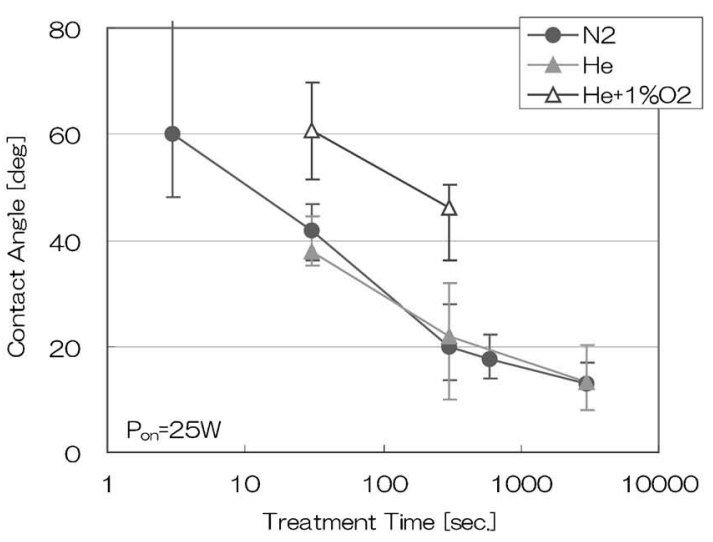

(a) PP based plymer

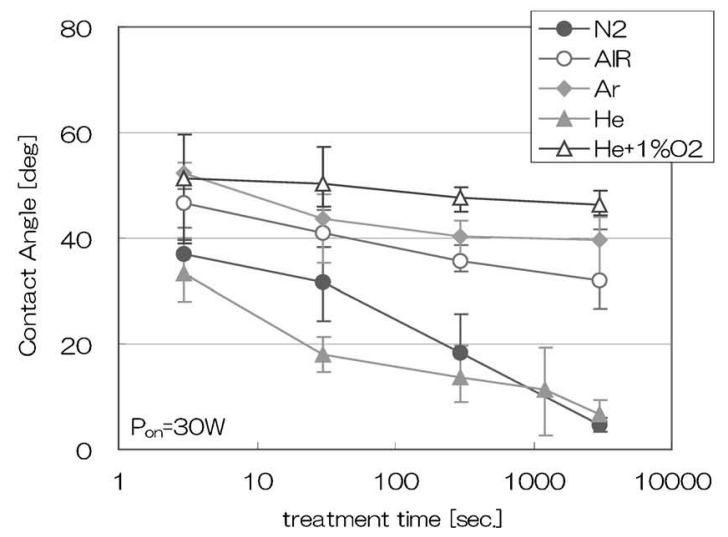

(b) HDPE

Fig. 4 Dependence of contact angle of water droplets on inner-surface of connector treated using atmospheric-pressure plasma generated by Type-B opposed coaxial electrodes under various gas conditions during treatment. Differences of the characteristics that depended on the material of the connector also were investigated: (a) with input power at RF$\mathrm{ON}$, the PP-based connector was treated while $\left(\mathrm{P}_{\text {on }}\right)$ was 25 $\mathrm{W}$; and (b) the HDPE connector was treated while $\mathrm{P}_{\text {on }}$ was $30 \mathrm{~W}$. The other conditions of the treatment were: total gasflow rate of $0.5 \mathrm{l} / \mathrm{min}$., time-modulation frequency of $600 \mathrm{~Hz}$, and duty cycle of 0.01 .

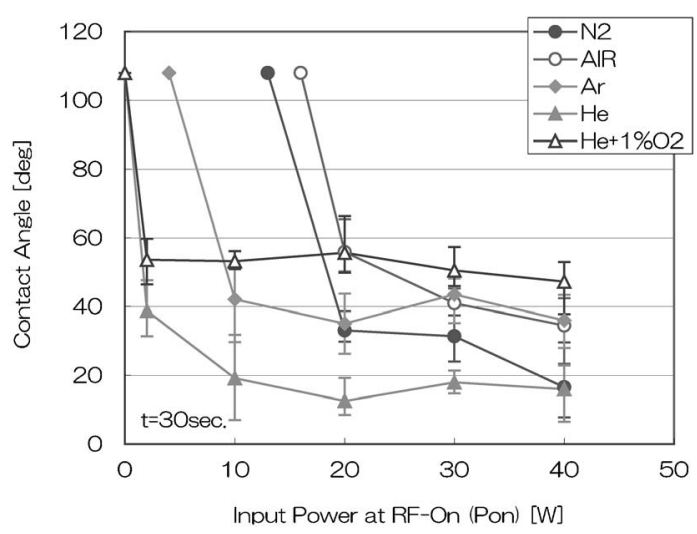

Fig. 5 Dependence of contact angle of water droplet on the inner surface of HDPE connector treated using atmosphericpressure plasma generated by Type-B opposed coaxial electrodes under various gas conditions with input power at RFOn. The conditions of the treatment were: total gas-flow rate of $0.5 \mathrm{l} / \mathrm{min}$., time-modulation frequency of $600 \mathrm{~Hz}$, duty cycle of 0.01 , and treatment time of $30 \mathrm{sec}$. 


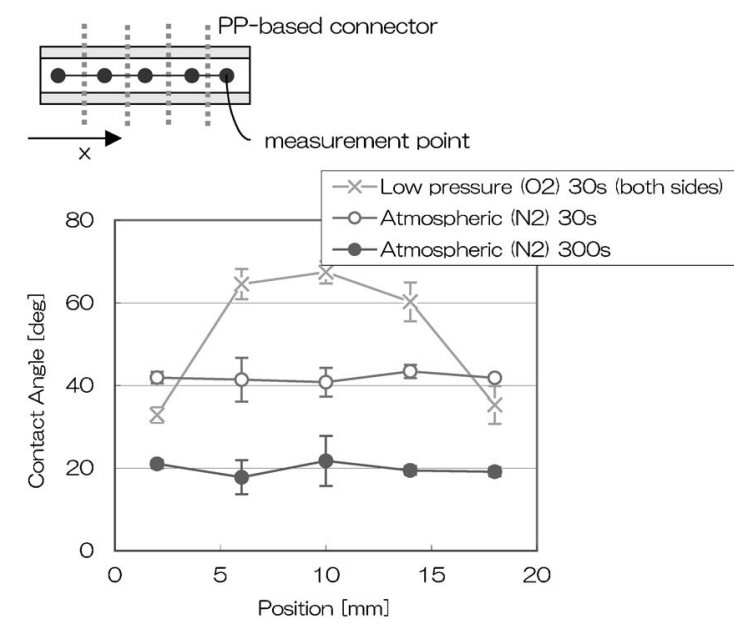

Fig. 6 Dependence of contact angle of water droplets on inner surface of PP-based connector treated by discharge plasmas on position (x). Effect of the inner-surface treatment by atmospheric-pressure $\mathrm{N}_{2}$ plasma using Type-B opposed coaxial electrodes was compared with treatment by conventional low-pressure $\mathrm{RF} \mathrm{O}_{2}$ plasma using parallel-plate-type electrodes. The conditions of the atmospheric-pressure plasma were: total gas-flow rate of $0.5 \mathrm{l} / \mathrm{min}$., time-modulation frequency of $600 \mathrm{~Hz}$, duty cycle of 0.01 , and input power of 25 $\mathrm{W}$ with RF-On. In the low-pressure plasma treatment, the connector was set up vertically on the anode and then treated by the plasma. In addition, the connector was reversed and then treated again. The conditions of the low-pressure plasma were: pressure of $20 \mathrm{~Pa}$, electrode gap of $70 \mathrm{~mm}$, and input $\mathrm{RF}$ power of $100 \mathrm{~W}\left(1.3 \mathrm{~W} / \mathrm{cm}^{2}\right)$.

事が判った， $\mathrm{N}_{2}$ を用いる事で，希ガスを必要としない大気 圧下での良好な親水化処理が可能である.

（2）処理の均一性

さらに，大気圧下のコネクタ内面の放電プラズマ処理で良 好な特性を示した $\mathrm{N}_{2}$ 処理について, 処理の均一性を確認し た. また，一般的な平行平板型の低圧プラズマ処理装置を選 び，コネクタ内面の処理の均一性を比較した.

$\mathrm{N}_{2}$ を用いて処理した直後における PP コネクタ内面の水 滴接触角の分布を Fig. 6 に示す. コネクタ内面用大気圧プ ラズマ処理では, 場所によらずほぼ一定の水滴接触角が得ら れており，ほぼ均質な処理ができている事が判る。これによ り，2.1節で述べた当初期待した効果(b)を確認する事ができ た.

一方，低圧プラズマ処理では，コネクタの上下を反転させ て2回処理を行ったにも関わらず, コネクタの端と中央 で, 水滴接触角に大きな違いがあり, コネクタ内部まで十分 に親水化する事ができていない.

今回開発した大気圧プラズマ処理は，低圧プラズマ処理と 異なり真空引きを必要としない事も考慮すると, 沉用の低圧 プラズマ処理に比ベ，コネクタ内面処理の均一性や処理速度 の点でも非常に優れていると言える.

\section{3 コネクタ内面の化学結合状態の分析}

$\mathrm{N}_{2}$ と $\mathrm{He}$ を用いて処理した場合に低い水滴接触角が得ら れたので, 処理表面の化学結合状態を確認するために, コネ クタ内面の XPS 分析を行った. 結果を Table 1 示す. 分子 構造が単純なため, 表面処理によるXPS スペクトルの変化
Table 1 Summary of analysis of inner-surface of HDPE connector treated using atmospheric-pressure plasma generated by Type-B opposed coaxial electrodes under various gas conditions by XPS. The conditions of the treatment were: total gas-flow rate of $0.5 \mathrm{l} / \mathrm{min}$., time-modulation frequency of 600 $\mathrm{Hz}$, duty cycle of 0.01 , input power of $30 \mathrm{~W}$ with $\mathrm{RF}-\mathrm{On}$, and treatment time of $300 \mathrm{sec}$

\begin{tabular}{|c|c|c|c|c|c|c|c|}
\hline & \multicolumn{3}{|c|}{$\begin{array}{c}\text { Composition } \\
\text { [at.\%] }\end{array}$} & \multicolumn{4}{|c|}{ C1s Peak Fitting $[\%]$} \\
\hline & $\mathrm{C}$ & $\mathrm{O}$ & $\mathrm{N}$ & $\begin{array}{c}\mathrm{pk} 1 \\
285.0 \mathrm{eV} \\
(\mathrm{C}-\mathrm{C}, \mathrm{C}-\mathrm{H})\end{array}$ & $\begin{array}{c}\mathrm{pk} 2 \\
286.5 \mathrm{eV} \\
(\mathrm{C}-\mathrm{O})\end{array}$ & $\begin{array}{c}\mathrm{pk} 3 \\
287.8 \mathrm{eV} \\
(\mathrm{C}=\mathrm{O}, \mathrm{C}-\mathrm{N})\end{array}$ & $\begin{array}{c}\mathrm{pk} 4 \\
289.3 \mathrm{eV} \\
(\mathrm{O}=\mathrm{C}-\mathrm{O})\end{array}$ \\
\hline Untreated & 97.1 & 2.9 & 0.0 & 95.6 & 4.4 & 0.0 & 0.0 \\
\hline $\mathrm{N}_{2}$ & 73.5 & 15.7 & 10.8 & 76.3 & 9.0 & 8.5 & 6.2 \\
\hline AIR & 74.5 & 24.6 & 0.9 & 68.7 & 12.5 & 9.0 & 9.8 \\
\hline $\mathrm{Ar}$ & 85.4 & 12.7 & 1.8 & 85.9 & 7.7 & 4.7 & 1.7 \\
\hline $\mathrm{He}$ & 89.2 & 9.3 & 1.5 & 90.8 & 6.1 & 2.3 & 0.8 \\
\hline $\mathrm{He}+1 \% \mathrm{O}_{2}$ & 83.8 & 15.5 & 0.7 & 81.1 & 9.2 & 5.7 & 4.0 \\
\hline
\end{tabular}

が解析し易いという理由から, HDPEコネクタの場合の結 果を示した。

親水性は, 表面に生成した酸素を含む官能基（ $-\mathrm{C}-\mathrm{O}$, $-\mathrm{C}-\mathrm{OH},-\mathrm{C}=\mathrm{O},-\mathrm{C}-\mathrm{OOH}$ 等）の量に相関する. 組成の 分析結果より, $\mathrm{O}$ の比率からコネクタ内表面の酸化の程度, 即ち酸素を含む親水官能基の量を見ると, その序列は，未処 理 $<\mathrm{He}<\mathrm{Ar}<\mathrm{He}+1 \% \mathrm{O}_{2}<\mathrm{N}_{2}<\mathrm{AIR}$ である. 一方, $\mathrm{O}=\mathrm{C}$ - O 結合の存在を表す C $1 \mathrm{~s}$ スペクトルの成分 $\mathrm{pk} 4$ の比率か らコネクタ内表面の酸化の度合いを見ると，その序列は，O の比率からみた序列と同じである。しかしながら, XPS 分 析でみたコネクタ内表面の酸化の度合いは，親水性を表すも う 1 つの指標である水滴接触角の序列（未処理 $>\mathrm{He}+1 \% \mathrm{O}_{2}$ $\left.>\mathrm{Ar}>\mathrm{AIR}>\mathrm{N}_{2} \sim \mathrm{He}\right)$ と必ずしも一致していない.

また, 組成の分析結果より, $\mathrm{N}_{2}$ 処理の場合, $\mathrm{N}$ の比率が 明らかに高く, コネクタ内面に窒素が導入されている事も判 った。

\section{4 放電プラズマの発光分光分析}

ガス種による処理特性の違いを調べるために，OES 測定 により, 放電プラズマの状態を診断した。結果を Fig. 7 に 示す.

$\mathrm{N}_{2}$ 処理の場合, $\mathrm{N}_{2}$ に関する発光のみが観測された. $\mathrm{AIR}$ 処理の場合, 弱い $\mathrm{N}_{2}$ の発光以外に微弱な原子状酸素 $(\mathrm{O})$ の発光を確認できた. He 処理の場合, He の発光以外に $\mathrm{O}$, $\mathrm{N}_{2}^{+}, \mathrm{N}_{2}, \mathrm{H}, \mathrm{OH}$ の発光が確認された. $\mathrm{He}+1 \% \mathrm{O}_{2}$ 処理では, $\mathrm{O}, \mathrm{He}$ の発光以外に $\mathrm{N}_{2}^{+}$と $\mathrm{N}_{2}$ の発光が確認された. $\mathrm{O}_{2}$ の添 加により, O の発光は増大し, $\mathrm{He}$ の発光は減少した. 一方, $\mathrm{Ar}$ 処理では, $\mathrm{Ar}$ の発光以外に $\mathrm{OH}$ と微弱な $\mathrm{N}_{2}$ の発光が観 測された. ガス種によっては, $\mathrm{O}, \mathrm{OH}$ 等本来無いはずの発 光も観測されており, 得られた結果は, 不純物ガスの影響を 含んでいる.

$\mathrm{He}, \mathrm{Ar}$ 及び $\mathrm{N}_{2}$ を含むガスでは, 高エネルギー準位に励 起された原子. 分子が発光して, 準安定状態のエネルギー準 位，またはそれよりも上位の準位に移行している事が確認で きている事から, 準安定な活性種 : $\mathrm{He}^{*}, \mathrm{Ar}^{*}, \mathrm{~N}_{2}^{*}$ の生成 

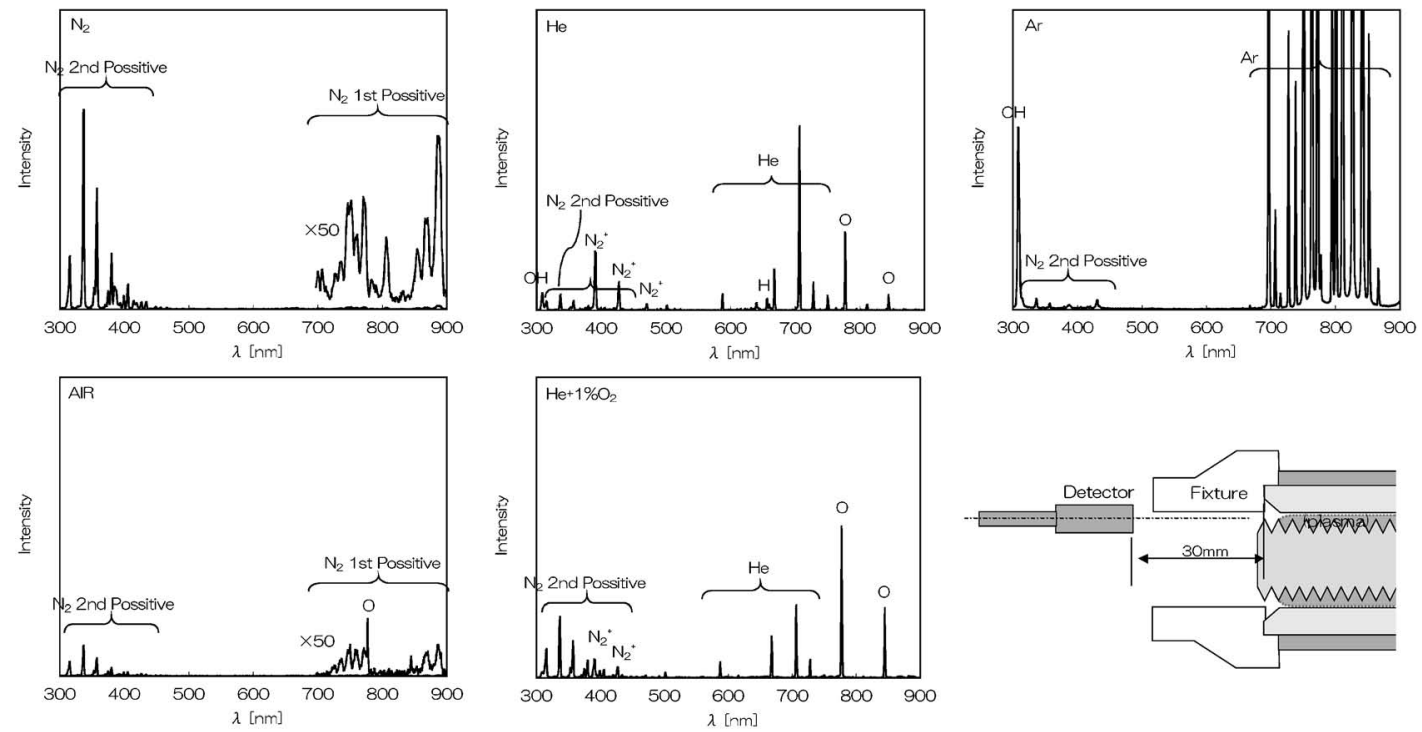

Fig. 7 Optical emission spectra of atmospheric-pressure plasma generated by Type-B opposed coaxial electrodes under various gas conditions. The setup for the measurement is shown in the lower right figure. The conditions of plasma generation were: total gas-flow rate of $0.5 \mathrm{l} / \mathrm{min}$., time-modulation frequency of $600 \mathrm{~Hz}$, duty cycle of 0.01 , and input power of $30 \mathrm{~W}$ with RF-On.

が示唆される．また, $\mathrm{He}+1 \% \mathrm{O}_{2}$ 処理の場合, $\mathrm{He}$ 処理に比 べ強い $\mathrm{O}$ の発光が確認されている事から, $\mathrm{O}$ の発光強度に 相関して，準安定な Oの生成も増えている事が考えられる.

発光分光で見る限り，放電プラズマにより生成された準安 定な活性種は, $\mathrm{N}_{2}$ 処理と AIR 処理では $\mathrm{N}_{2}^{*}, \mathrm{He}$ 処理では $\mathrm{He}^{*}, \mathrm{He}+1 \% \mathrm{O}_{2}$ 処理では $\mathrm{He}^{*}$ と $\mathrm{O}, \mathrm{Ar}$ 処理では $\mathrm{Ar}^{*} か ゙$ 主 体であると推定される.

\section{4. 考察}

ここでは，上記の結果をもとに，プラズマ処理で改質され た表面の状態のガス種による違いに着目して議論する. 注目 すべき点を 3 点挙げ， $\mathrm{He}$ と $\mathrm{N}_{2}$ の場合に良好な水滴接触角 が得られた理由について考察を行った。

今回開発した大気圧プラズマ処理では， $\mathrm{N}_{2}$ と $\mathrm{He}$ を用い た場合に低い水滴接触角が得られた. しかし, 酸素を含む官 能基 $(-\mathrm{C}-\mathrm{O},-\mathrm{C}-\mathrm{OH},-\mathrm{C}=\mathrm{O},-\mathrm{C}-\mathrm{OOH}$ 等) の量に関 係する表面の酸化の度合いに抢けるガス種の序列（未処理< $\left.\mathrm{He}<\mathrm{Ar}<\mathrm{He}+1 \% \mathrm{O}_{2}<\mathrm{N}_{2}<\mathrm{AIR}\right)$ は，水滴接触角の序列 (未処理 $>\mathrm{He}+1 \% \mathrm{O}_{2}>\mathrm{Ar}>\mathrm{AIR}>\mathrm{N}_{2} \sim \mathrm{He}$ ) と必ずしも一致 していなかった。これは, 水滴接触角は, 最表面の官能基の 種類と量を反映しているのに対し，XPSで見た酸化の度合 いは，数 $\mathrm{nm}$ までの深さ情報を平均したものであり，表面改 質層の酸化の程度を表しているという違いを反映したのであ ると考える事ができる.

一般に，プラズマ処理による親水化機構9-11) としては，放 電プラズマにより生じた $\mathrm{O}$ や $\mathrm{OH}$ 等の活性種が高分子材料 表面に照射され，分子鎖に親水官能基を形成して親水化する 場合と，分子鎖にラジカルを形成して，処理後に瞬時に空気 中の酸素, 窒素や水蒸気等と反応して親水官能基が導入され 親水化する場合の 2 通りを考える必要がある.

また，高分子表面では，高いエネルギーを持つ活性種照射 されると，分子鎖を切断し，低分子量化が進行する．やが
て, 揮発成分を生成し, いわゆる化学的/物理的なエッチン グが起こる11). また，競合して分子鎖の架橋反応も進行す るとされている。このような架橋反応の進行は, $\mathrm{He}^{*}$ のよ うな非常に高いエネルギーレベルに励起された準安定な活性 種が照射された時によく見られ，CASING (Crosslinking by Activated Species of Inert Gas）と呼ばれている12).

一方，高分子鎖に生成した親水官能基は，時間経過に伴 い, 反転して高分子内部に移行し, 高分子表面の親水性が劣 化する事が知られている13,14).

今回 AIR 処理で見られた，XPS で分析すると表面が良く 酸化されているが，水滴接触角は大きいという高分子表面 は, 上記の知見を参考にすると, 親水化処理した後に経時変 化させた表面状態と等しいと考える事ができる. プラズマ処 理により生成した親水官能基が反転して高分子内部に移行 し, 高分子内部の疎水基が最表面に現れた状態を想定すれば よい，因みに，親水化処理した後に経時変化させた高分子表 面を角度分解XPS で分析した結果が報告されており，表層 の酸素濃度が低く, 内部の酸素濃度が高いという解析結果が 得られている14).

AIR 処理では, 処理直後の水滴接触角が大きい事から, 酸素原子を含む親水官能基の反転が即座に起こっていると考 えられる．親水官能基の反転は，分子鎖の運動が容易になる 場合に促進され, 分子鎖が低分子量化した場合や, 高分子表 面の温度が高い場合が考えられる，AIR 処理では，少なく とも, 弱い $\mathrm{N}_{2}$ の発光以外に微弱な原子状酸素 $(\mathrm{O})$ の発光 を確認できている事から， $\mathrm{N}_{2}^{*}$ と O が低分子量化に寄与して いると推察される. $\mathrm{N}_{2}^{*}$ は, $\mathrm{He}^{*}$ や $\mathrm{Ar}^{*}$ と同様に, 分子鎖を 切断するに十分なエネルギーの UV 光 $(6.2 \mathrm{eV})$ を発するだ けのポテンシャルをもつ ${ }^{8)}$. $\mathrm{N}_{2}^{*}$ の照射により分子鎖は切断 され，近傍に $\mathrm{O}$ があると分子鎖の末端が $\mathrm{O}$ で修飾され低分 子量化していくモデルが考えられる.

また AIR 処理では, 他のガス種に比べ, 発光強度が全般 
的に低い事から，活性種の密度が低い事が予想されるそその ため, 過度の低分子量化（揮発成分の生成）が進行し難く, XPS 分析で得られる表面の酸化の程度が高くなっているの ではないかと考える.

第 2 に注目すべき点として，低い水滴接触角が得られた $\mathrm{He}$ 処理及び $\mathrm{N}_{2}$ 処理では，不純物ガスを除き，積極的に $\mathrm{O}_{2}$ を添加していない事が挙げられる. 反対に， $\mathrm{O}_{2}$ を含む $\mathrm{He}+$ $1 \% \mathrm{O}_{2}$ 処理は, $\mathrm{AIR}$ 処理とともに水滴接触角が大きい.

$\mathrm{He}+1 \% \mathrm{O}_{2}$ 処理では, $\mathrm{O}, \mathrm{He}$ の発光が確認できている事 から, AIR 処理の場合々同様, $\mathrm{He}^{*}$ と $\mathrm{O}$ が低分子量化に寄 与していると推察される。 また, $\mathrm{He}+1 \% \mathrm{O}_{2}$ 処理では, 非 常に強い $\mathrm{O}$ の発光が観測されている事から, 活性種密度が 高い事が予想され，AIR 処理に比べ低分子量化がより進行 し, 高分子表面がエッチングされ易いと考えられる.よって, $\mathrm{He}+1 \% \mathrm{O}_{2}$ 処理において, 水滴接触角が大きい理由は, 親 水官能基の反転に加え，揮発成分の生成により表面から親水 官能基が除去されるためであると思われる.

一方, $\mathrm{He}$ 処理では, 不純物ガスの混入による $\mathrm{O} の$ 発光は 観測されているものの, Fig. 3 に示したように, 放電開始電 力が非常に小さい事から, 混入した $\mathrm{O}_{2}$ 量は微量であり, $\mathrm{O}$ の生成量は僅かであると思われる. そのため, He 処理では, $\mathrm{He}+1 \% \mathrm{O}_{2}$ 処理と異なり, $\mathrm{He}^{*}$ が照射され分子鎖が切断さ れても，O による分子鎖末端の修飾の影響が少ないため，低 分子量化が進行し難く, 一方で CASING と呼ばれる分子鎖 の架橋反応も進行すると考えられる.これにより, He 処理 では，低分子量化が抑制された高分子表面に多くのラジカル が生成される事になる. He 処理において, 水滴接触角が小 さい理由は，このような処理表面が，処理後に瞬時に空気中 の酸素や水蒸気等と反応して多量の親水官能基が導入される ためであると考える。

第 3 に注目すべき点として, $\mathrm{N}_{2}$ 処理では, 高分子表面に 窒素が導入されている点である. 同じ $\mathrm{N}_{2}$ ガスを主体とする AIR 処理では, 窒素の導入は確認できて抢らず， O が共存 する場合は, 窒素が導入される反応が進行し難いと考えられ る. また, $\mathrm{N}_{2}$ 処理では, $\mathrm{N}_{2}$ に関連した発光のみが観測され ており, 活性種の主体は $\mathrm{N}_{2}^{*}$ であり, $\mathrm{O}$ は殆ど存在しない. $\mathrm{N}_{2}$ 処理では, $\mathrm{He}$ 処理と同様, $\mathrm{O}$ による分子鎖末端の修飾の 影響が少ないため，低分子量化が進行し難くいと考えられる. $\mathrm{N}_{2}$ 処理では, 水滴接触角が低い結果が得られているので, 分子鎖への窒素の導入は, 低分子量化が進行し難くする効果 を有していると推定される.

$\mathrm{Ar}$ 処理に対する考え方は，同じ希ガスである $\mathrm{He}$ 処理と 同様であると思われるが，それに反して $\mathrm{Ar}$ 処理では， He 処理と違い, 水滴接触角は大きな值を示す. また, $\mathrm{Ar}$ 処理 では, 実際に Arに関連する発光の他に, 非常に強い $\mathrm{OH} の$ 発光が観測されている. Ar 処理において水滴接触角は大き な值を示す理由は, $\mathrm{OH}$ が $\mathrm{He}+1 \% \mathrm{O}_{2}$ 処理に打ける $\mathrm{O}$ と同 じ作用をするためではなかいと考えている.

以上から, $\mathrm{He}$ と $\mathrm{N}_{2}$ がスの場合に良好な水滴接触角が得 られた理由は, 分子末端を修飾する $\mathrm{O}$ が共存しない環境下 で, $\mathrm{He}^{*} や \mathrm{~N}_{2}^{*}$ のような準安定な活性種が高分子鎖に照射さ れる事により，低分子量化が抑制された高分子表面に多くの
ラジカルが生成され, 処理後に空気中の酸素や水蒸気等と反 応して多量の親水官能基が導入されるためであると考えてい る.

今後, 上記の議論をより確実なものにするためには, プラ ズマ処理した表面を溶媒で洗浄し, 低分子量成分を除去した 場合の水滴接触角の測定やXPS 分析など, さらなる実験が 必要である。

\section{5. ま と め}

高周波電力を用いたチューブコネクタ用内面大気压プラズ マ処理装置を開発し，それを用いてチューブコネクタ内面の 親水化を試みた。

(1) 電極上への微小な螺旋溝の形成と時間变調した RF 電 力の印加により, 希ガスを用いずに $\mathrm{N}_{2}$ や空気で安定した放 電プラズマを形成できた.

（2）ガスの種類を変更して処理をしたところ，コネクタの 材質によらず， $\mathrm{N}_{2}$ と $\mathrm{He}$ を用いた場合に，20 deg 以下の低 い水滴接触角が得られた. 特に, $\mathrm{N}_{2}$ を用いる事で, 希ガス を必要としない大気圧下での良好な親水化処理が可能であ る.

（3）また，汎用の低圧プラズマ処理と比較したところ，低 圧プラズマ処理では，コネクタの端と中央で水滴接触角に大 きな違いがあるのに対し, 本手法では, 場所によらずほぼ一 定の水滴接触角が得られて抢り, 均質なコネクタの内面処理 が可能である.

（4）一方, $\mathrm{He}$ と $\mathrm{N}_{2}$ ガスの場合に良好な水滴接触角が得 られた理由としては, 分子末端を修飾する O が共存しない 環境下で, $\mathrm{He}^{*} や \mathrm{~N}_{2}^{*}$ のような準安定な活性種が高分子鎖に 照射される事により，低分子量化が抑制された高分子表面に 多くのラジカルが生成され, 処理後に大気と反応して多量の 親水官能基が導入されるためであると考えている.

\section{[文献〕}

1）“小特集 大気圧グロー放電の発生と応用”，プラズマ・核融 合学会誌, 79 (2003) 1000.

2) 児玉 亮: 真空, 44 (2001) 80 .

3）堤井信力, 小野 茂: “プラズマ気相反応工学”, 内田老鶴戋 (2000) 104.

4) 小田川健二, 貞本 満, 小野茂, 堤井信力：真空, 48 (2005) 67.

5) G. Beamson and D. Briggs: "High Resolution XPS of Organic Polymers. The Scienta ESCA300 Database.", John Wiley \& Sons Ltd., Chichester (1992).

6）大田理一郎, 李 庚晃, 齋藤永宏, 井上泰志, 杉村博之, 高 井 治: 表面技術, 54 (2003) 769.

7) NIST Atomic Spectra Database: http://physics.nist.gov/cgi-bin/AtData/main_asd

8) R. W. B. Pearse and A. G. Gaydon: "4th Ed. The Identification of Molecular Spectra", John Wiley \& Sons Inc., New York (1976).

9）小駒益弘：表面技術，51（2000） 147.

10）角田光雄 : 塗装技術，1988年 1 月号（1988） 100.

11) 稲垣訓宏 : 化学工業, 41 (1990) 497.

12) H. Schonhorn and R. H. Hansen: J. Appl. Polym. Sci., 11 (1967) 1461.

13）筏 義人, 松永忠与, 鈴木昌和：日本化学会誌, 1985年 6 月 号（1985） 1079.

14）多留康矩, 小林光一, 高砂子昌久, 高岡 京, 荒井正義 : 高 分子論文集，53 (1996) 96. 